\title{
Limnology in the Upper Paraná River floodplain: large-scale spatial and temporal patterns, and the influence of reservoirs
}

\author{
Roberto, MC. ${ }^{\mathrm{a}}$, Santana, $N F^{\mathrm{b}}$, and Thomaz, $S M{ }^{\mathrm{c}}$ \\ ${ }^{a}$ Laboratório de Limnologia Básica - LLB, Núcleo de Pesquisa em Limnologia, Ictiologia e Aqüicultura - Nupelia, \\ Universidade Estadual de Maringá - UEM, \\ Av. Colombo, 5790, CEP 87020-900, Maringá, PR, Brazil

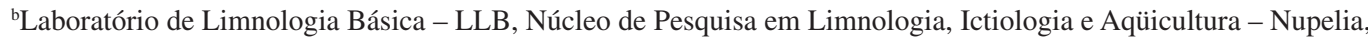 \\ Programa de Pós-Graduação em Ecologia de Ambientes Aquáticos Continentais - PEA, \\ Universidade Estadual de Maringá - UEM, \\ Av. Colombo, 5790, CEP 87020-900, Maringá, PR, Brazil \\ 'Departamento de Biologia - DBI, Núcleo de Pesquisa em Limnologia, Ictiologia e Aqüicultura - Nupelia, \\ Universidade Estadual de Maringá - UEM, \\ Av. Colombo, 5790, CEP 87020-900, Maringá, PR, Brazil \\ *e-mail: mcroberto@nupelia.uem.br
}

Received December 5, 2008 - Accepted May 4, 2009 - Distributed June 30, 2009

(With 5 figures)

\begin{abstract}
Knowledge of abiotic limnological factors is important to monitor changes caused by humans, and to explain the structure and dynamics of populations and communities in a variety of inland water ecosystems. In this study, we used a long term data-set (eight years) collected in 10 habitats with different features (river channels, and connected and isolated lakes) to describe the spatial and temporal patterns of some of the principal limnological factors. In general, the degree of connectivity of the lakes, together with the rivers to which the lakes are connected, were important determinants of their limnological characteristics. These differences are expected, because rivers entering the floodplain come from different geological regions and are subject to different human impacts. At large spatial scales, these differences contribute to the increased habitat diversity of the floodplain and thus to its high biodiversity. With regard to temporal variation, Secchi-disk transparency increased, and total phosphorus decreased in the Paraná River main channel during the last 20 years. Although these changes are directly attributed to the several reservoir cascades located upstream, the closing of the Porto Primavera dam in 1998 enhanced this effect. The increase in water transparency explains biotic changes within the floodplain. The lower-phosphorus Paraná River water probably dilutes concentrations of this element in the floodplain waterbodies during major floods, with future consequences for their productivity.
\end{abstract}

Keywords: floodplain, abiotic factors, temporal and spatial variation, productivity.

\section{Limnologia na planície de inundação do Alto Rio Paraná: padrões em amplas escalas espaciais e temporais e influência de reservatórios}

\section{Resumo}

Fatores limnológicos abióticos têm sido importante para monitorar as mudanças causadas pelo homem e para explicar a estrutura e a dinâmica de populações e comunidades em uma variedade de ecossistemas aquáticos. Neste estudo, foram usados dados de vários anos (oito anos) coletados em 10 habitats com características distintas (rios, canais, lagoas isoladas e conectadas) para descrever padrões espaciais e temporais de alguns fatores limnológicos. Em geral, o grau de conectividade das lagoas com o rio ao qual estão conectadas foi importante para determinar as suas características limnológicas. Estas diferenças são esperadas porque os rios que chegam à planície de inundação vêm de diferentes regiões geológicas e estão sujeitos a diferentes impactos humanos. Em grandes escalas espaciais, tais diferenças contribuem para o aumento da diversidade de habitats da zona sujeita a inundações e assim, a sua alta biodiversidade. A respeito da variação temporal, observou-se um aumento nos valores de disco de Secchi e diminuição na carga de fósforo total no canal principal do rio Paraná nos últimos 20 anos. Embora estas mudanças estejam diretamente atribuídas ao efeito cascata de vários reservatórios a montante, o fechamento da represa de Porto Primavera em 1998 realçou este efeito. O aumento na transparência da água explica as mudanças bióticas observadas na planície 
de inundação. Em função das baixas concentrações de fósforo no rio Paraná, este está provavelmente diluindo a sua planície de inundação durante as grandes cheias, o que poderá acarretar em efeitos negativos para a sua produtividade no futuro.

Palavras-chave: planície de inundação, fatores abióticos, variação temporal e espacial, produtividade.

\section{Introduction}

River-floodplain systems are important ecosystems in the neotropics, where they occur in great numbers, occupy large areas, and are highly diverse (Neiff, 2001; Tundisi and Matsumura-Tundisi, 2008). The structure and dynamics of these ecosystems are maintained mainly by water-level fluctuations (Junk et al., 1989; Neiff, 1990; Agostinho and Zalewski, 1995), but other regional factors such as temperature and photoperiod may also be important.

Although recognized as a single ecosystem, riverfloodplain ecosystems encompass a variety of habitats including lotic and lentic waterbodies, marshes, and other types of habitats completely covered by aquatic vegetation; transition zones between aquatic and terrestrial habitats; and riparian zones. These habitats differ in their physical and chemical properties in response to water depth, water velocity, and the degree of connectivity and influence of local tributaries, among other driving forces (e.g., Tockner et al., 2000; Thomaz et al., 2004; 2007). In turn, their populations also change according to physical and chemical features (Junk et al., 1989); the high biodiversity at large spatial scales may be explained by habitat heterogeneity provided by differences in physical and chemical properties (Tockner et al., 2000; Marchese et al., 2005).

In addition, floodplain physical and chemical properties are also strongly affected by the human use of river basins. In South America, reservoirs have been constructed in most of the main rivers (Tundisi and MatsumuraTundisi, 2008), and their operation strongly affects the floodplains (Agostinho and Zalewski, 1995; Neiff, 2001; Hoeinghaus et al., 2008).

Although the effects of water-level fluctuations on physical habitats are relatively well studied, most investigations have been carried out in Europe and North America (Leira and Cantonati, 2008). Because of the strong influence of physical and chemical features on organisms, part of the structure and dynamics of populations and communities in floodplains can be explained by the dynamics of abiotic factors. Thus, besides offering an opportunity to monitor anthropogenic transformations in floodplains, understanding the physical and chemical aspects also helps to explain the structure and dynamics of biotic communities.

In this study, we investigated abiotic limnological factors in different habitats of the Upper Paraná River floodplain. Our main objectives were i) to examine whether the upstream reservoirs (especially Porto Primavera) affected limnological factors (mainly phosphorus and Secchi depth) and ii) to evaluate the influence of different rivers (Paraná, Ivinheima and Baía) on limnology and diversity of aquatic habitats in the floodplain. To accomplish these objectives, we assessed patterns observed over long spatial (three river channels, four lakes directly connected and another three lakes isolated from the main rivers) and temporal (eight years) scales.

\section{Material and Methods}

Water levels were measured daily by a gauge installed in the Field Station of the University of Maringá. Water samples were collected in the following environments in the Upper Paraná River floodplain (which will be referred to as "habitats"; Figure 1):

- Lakes Osmar, Fechada, and Ventura: these are isolated lakes that remain unconnected to the main river channel for most of the year, and receive water from overbank flow only during exceptionally high-water periods; these lakes are in the basins of the Paraná, Baía and Ivinheima rivers respectively;

- Lakes Garças, Pau-véio (connected to the Paraná River), Guaraná, and Patos (connected to the rivers Baía and Ivinheima, respectively): these lakes are permanently connected to their rivers through short canals; and

- Main channels of the rivers Paraná, Baía and Ivinheima.

A total of 29 sample series were taken at irregular intervals (three to six months) from February 2000 to February 2008. In each of these 29 samples, water was collected with a van Dorn bottle from the sub-surface layer in one point situated in the pelagic zone of all habitats. We used only sub-surface water in our analysis because: i) our main intention was to focus on long-term (eight years) and a large spatial scale (different habitats belonging to different basins within the floodplain), and ii) all the habitats are quite shallow (in general, depths $<3.0 \mathrm{~m}$, except the rivers), and previous studies (e.g., Thomaz et al., 2004) showed that physical and chemical differences in the water column are uncommon, and develop only during high-water periods. The water was immediately analyzed for $\mathrm{pH}$ and conductivity (Digimed portable meters), and total alkalinity (Gran titration; Carmouze, 1994). Water transparency was measured with a $0.30 \mathrm{~m}$ black and white Secchi disk, and temperature and oxygen with a YSI meter.

The water samples were stored in an ice chest and taken to the University of Maringá field station, where they were filtered through GF $52-\mathrm{C}$ membranes $(<10$ hours af- 


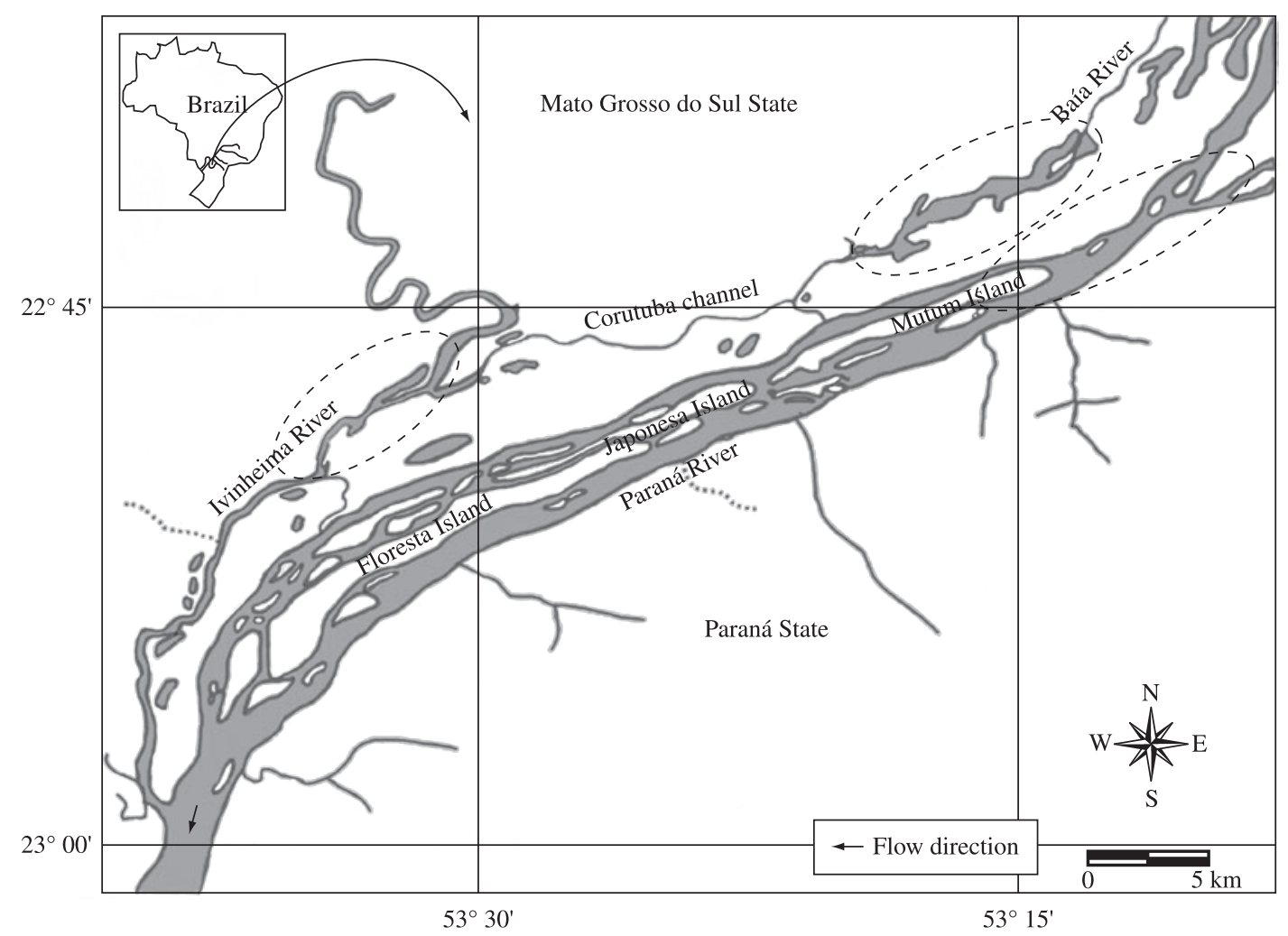

Figure 1. Map of the Paraná River and its floodplain. Dashed lines indicate regions where the habitats associated to the Paraná, Baía and Ivinheima rivers are situated.

ter sampling) and immediately frozen $\left(-20^{\circ} \mathrm{C}\right)$ for further analyses of dissolved nutrients. Water was also frozen at $-20{ }^{\circ} \mathrm{C}$ before filtering to measure total nitrogen and total phosphorus. Membranes were used to quantify chlorophyll (acetone extraction and reading in a spectrophotometer, according to Golterman et al., 1978).

Total-N was analyzed with the persulfate method with oxidations of all nitrogenous compounds to N-nitrate (Bergamin et al., 1978). This ion was determined in a spectrophotometer after reducing N-nitrite in the presence of cadmium, using a flow-injection system (Giné et al., 1980). N-ammonium was quantified by the indophenol blue method, also read in a spectrophotometer (Mackereth et al., 1978). Total and reactive dissolved $\mathrm{P}$ were measured in a spectrophotometer, according to Golterman et al. (1978).

Because we observed clear changes of phosphorus concentration and water transparency of the Paraná River in the last 20 years (see Results), we focused more on these two variables. We used results obtained in sample series from 1986-1988 (Thomaz, 1991) and 1991-1994 (FUEM/PADCT/CIAMB, 1995) to compare with more recent data obtained from 2000-2008. Comparisons were restricted to these two variables because there were no data for dissolved nutrients from the first two periods. Total nitrogen could also not be compared, because of differences in the methods employed in these three periods.

Because of the large number of variables (11) obtained in highly diverse habitats (rivers, and connected and isolated lakes) during a long period (ca. eight years), we applied a principal components analysis (PCA) to summarize the abiotic data and search for spatial and temporal patterns. An Analysis of Variance was applied to test differences in the first principal-components scores among habitats associated with different rivers. Correlation was applied to test the relationship between the water level of the Paraná River and the concentrations of phosphorus in the lakes associated with the different rivers. All analyses were carried out with the Program Statistica 7.0.

\section{Results}

\subsection{Water-level fluctuations}

The water levels of the Paraná River measured from 2000 to 2008 showed a pattern with high water levels usually predominating from December to March (Figure 2). However, these periods were characterized by wide fluctuations over short time periods (1-7 days). The driest period was observed in 2001, when the water levels decreased to lower than $2 \mathrm{~m}$. Three major floods occurred: in February-March 2002 (short duration, water 
levels $>4.5 \mathrm{~m}$ for 9 days), in January-February 2005 (medium duration, water levels $>4.5 \mathrm{~m}$ for 29 days) and from January-March 2007 (long duration, water levels > $4.5 \mathrm{~m}$ for 57 days) (Figure 2).

\subsection{Spatial patterns}

In general, there were wide fluctuations in all variables (Table 1). On average, oxygen concentrations were higher than $7.0 \mathrm{mg} . \mathrm{L}^{-1}$ and $\mathrm{pH}$ was close to neutral. Habitats had high turbidity (low Secchi disk depths); the Paraná River main channel had the most transparent waters. The highest levels of chlorophyll, total- $\mathrm{N}$, total-P and $\mathrm{N}_{-} \mathrm{NH}_{4}{ }^{+}$were recorded in lakes. The highest $\mathrm{N}_{-} \mathrm{NO}_{3}{ }^{-}$concentrations were found in isolated lakes and in the Paraná River (Table 1).

The first two axes of the PCA explained $50.3 \%$ of the total variability $(33.6 \%$ and $16.7 \%$ on axes 1 and 2 ,

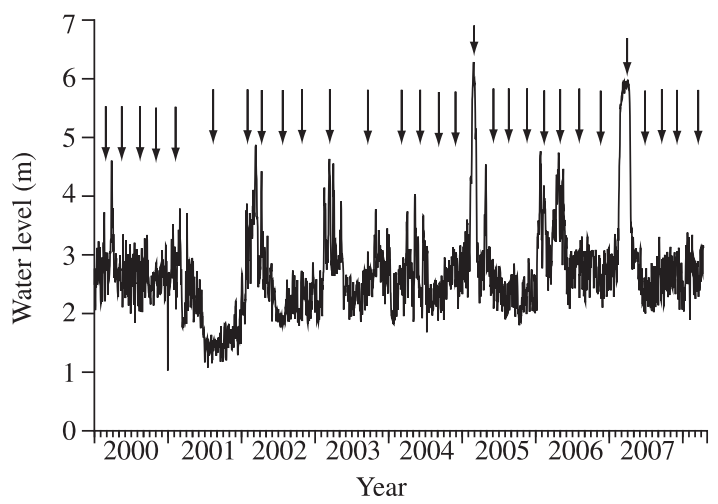

Figure 2. Daily measurements of relative water-level fluctuation in the Upper Paraná River (data obtained at the Field Station of the Maringá State University).

Table 1. Mean values, standard deviations (in parentheses), amplitude of variation, and number of samples (n) of the main limnological variables measured from 2000 to 2008 in habitats of the Upper Paraná River floodplain.

\begin{tabular}{|c|c|c|c|c|c|}
\hline Variables & $\begin{array}{c}\text { Connected } \\
\text { Lakes }\end{array}$ & $\begin{array}{c}\text { Isolated } \\
\text { Lakes }\end{array}$ & $\begin{array}{c}\text { Paraná } \\
\text { River }\end{array}$ & $\begin{array}{c}\text { Ivinheima } \\
\text { River }\end{array}$ & $\begin{array}{c}\text { Baía } \\
\text { River }\end{array}$ \\
\hline \multirow{3}{*}{$\begin{array}{l}\text { Dissolved oxygen } \\
\left(\mathrm{mg} \cdot \mathrm{L}^{-1}\right)\end{array}$} & $7.2(0.9)$ & $7.5(0.9)$ & $7.9(1.1)$ & $7.0(1.3)$ & $6.6(1.5)$ \\
\hline & $0.2-9.4$ & $0.7-10.9$ & $4.6-10.1$ & $2.7-8.7$ & $1.8-8.7$ \\
\hline & $\mathrm{n}=58$ & $\mathrm{n}=57$ & $\mathrm{n}=29$ & $\mathrm{n}=29$ & $\mathrm{n}=29$ \\
\hline \multirow[t]{3}{*}{$\mathrm{pH}$} & $7.2(0.4)$ & $7.0(0.5)$ & $7.2(0.4)$ & $7.0(0.5)$ & $6.5(0.5)$ \\
\hline & $4.8-8.5$ & 5.3-8.9 & $6.0-8.2$ & $6.1-8.4$ & 5.3-7.2 \\
\hline & $\mathrm{n}=58$ & $\mathrm{n}=57$ & $\mathrm{n}=29$ & $\mathrm{n}=29$ & $\mathrm{n}=29$ \\
\hline \multirow{3}{*}{$\begin{array}{l}\text { Conductivity } \\
\left(\mu \mathrm{S} . \mathrm{cm}^{-1}\right)\end{array}$} & $44.5(5.8)$ & $43.4(7.0)$ & $57.1(5.4)$ & $43.6(4.3)$ & $33.0(9.5)$ \\
\hline & $24.4-58.2$ & $15.9-60.4$ & $47.9-71.8$ & $32.7-54.4$ & $21.2-54.2$ \\
\hline & $\mathrm{n}=58$ & $\mathrm{n}=57$ & $\mathrm{n}=29$ & $\mathrm{n}=29$ & $\mathrm{n}=29$ \\
\hline \multirow{3}{*}{$\begin{array}{l}\text { Alkalinity } \\
\left(\mu g . L^{-1}\right)\end{array}$} & $302(53)$ & $278(79)$ & 354 (76) & $332(86)$ & $182(79)$ \\
\hline & $25-440$ & $12-463$ & $137-515$ & $112-487$ & $30-362$ \\
\hline & $\mathrm{n}=58$ & $\mathrm{n}=57$ & $\mathrm{n}=29$ & $\mathrm{n}=29$ & $\mathrm{n}=29$ \\
\hline \multirow{3}{*}{$\begin{array}{l}\text { Secchi depth } \\
(\mathrm{m})\end{array}$} & $0.8(0.3)$ & $0.6(0.5)$ & $3.0(1.2)$ & $0.7(0.3)$ & $0.8(0.3)$ \\
\hline & $0.1-1.6$ & $0.1-2.4$ & $1.4-5.5$ & $0.5-1.7$ & $0.5-1.5$ \\
\hline & $\mathrm{n}=58$ & $\mathrm{n}=57$ & $\mathrm{n}=29$ & $\mathrm{n}=29$ & $\mathrm{n}=29$ \\
\hline \multirow{3}{*}{$\begin{array}{l}\text { Chlorophyll } \\
(\chi)\end{array}$} & $16.2(10.1)$ & $21.9(18.2)$ & $2.3(3.3)$ & $1.4(2.2)$ & $8.4(6.8)$ \\
\hline & nd-46.9 & $0.6-89.5$ & $0.3-16.2$ & nd-11.7 & $0.9-34.1$ \\
\hline & $\mathrm{n}=58$ & $\mathrm{n}=57$ & $\mathrm{n}=29$ & $\mathrm{n}=29$ & $\mathrm{n}=29$ \\
\hline \multirow{3}{*}{$\begin{array}{l}\text { Total nitrogen } \\
\left(\mu \mathrm{g} \cdot \mathrm{L}^{-1}\right)\end{array}$} & $1018(415)$ & 1536 (919) & 372 (234) & 440 (334) & $566(393)$ \\
\hline & $212-2097$ & $278-4473$ & 89-974 & $143-1589$ & $184-1736$ \\
\hline & $\mathrm{n}=58$ & $\mathrm{n}=57$ & $\mathrm{n}=29$ & $\mathrm{n}=29$ & $\mathrm{n}=29$ \\
\hline \multirow{3}{*}{$\begin{array}{l}\text { N-Nitrate } \\
\left(\mu \mathrm{g} . \mathrm{L}^{-1}\right)\end{array}$} & $63(24)$ & $149(55)$ & $140(50)$ & $114(54)$ & $21(25)$ \\
\hline & nd-127 & nd-238 & $14-235$ & 4-214 & nd-95.0 \\
\hline & $\mathrm{n}=58$ & $\mathrm{n}=57$ & $\mathrm{n}=29$ & $\mathrm{n}=29$ & $\mathrm{n}=29$ \\
\hline \multirow{3}{*}{$\begin{array}{l}\text { N-ammonium } \\
\left(\mu \mathrm{g} \cdot \mathrm{L}^{-1}\right)\end{array}$} & $30(18)$ & 68 (99) & $9(8)$ & $9(6)$ & $24(28)$ \\
\hline & nd-89 & nd-530 & nd-37 & nd-23 & nd-119 \\
\hline & $\mathrm{n}=58$ & $\mathrm{n}=57$ & $\mathrm{n}=28$ & $\mathrm{n}=29$ & $\mathrm{n}=29$ \\
\hline \multirow{3}{*}{$\begin{array}{l}\text { Total Phosphorus } \\
\left(\mu g . L^{-1}\right)\end{array}$} & $78(48)$ & $133(44)$ & $12(8)$ & 39 (13) & 38 (16) \\
\hline & $13-314$ & $21-290$ & $3-47$ & 13-83 & 14-73 \\
\hline & $\mathrm{n}=58$ & $\mathrm{n}=57$ & $\mathrm{n}=29$ & $\mathrm{n}=29$ & $\mathrm{n}=29$ \\
\hline \multirow{3}{*}{$\begin{array}{l}\text { Reactive dissolved - P } \\
\left(\mu \mathrm{g} \cdot \mathrm{L}^{-1}\right)\end{array}$} & $13(4)$ & 25 (19) & $3(2)$ & $14(7)$ & $8(5)$ \\
\hline & $0.8-24$ & nd-93 & nd-11 & nd-32 & nd-19 \\
\hline & $\mathrm{n}=58$ & $\mathrm{n}=57$ & $\mathrm{n}=27$ & $\mathrm{n}=29$ & $\mathrm{n}=29$ \\
\hline
\end{tabular}

nd $=$ not detected 
respectively). The first axis was the only significant one according to the Broken-Stick model, and was affected positively by Secchi disk, conductivity and alkalinity, and negatively by total-P and total-N. The second axis was influenced positively by N-nitrate and negatively by chlorophyll (Figure 3a).

In general, habitats associated with each river were more similar to each other, but more dissimilar from habitats associated with other rivers (Figure $3 b$ ). The scores of the first axis were significantly different among these three eco-regions, represented by the Paraná, Baía and Ivinheima rivers and their associated lakes $(\mathrm{F}=57.4$; $\mathrm{p}<0.001$ ). Fechada Lake (an isolated habitat) had the lowest scores, indicating that this lake is richer in phosphorus and nitrogen. The Paraná River main channel together with its connected habitats (Pau-Véio and Garças lakes) and the Ivinheima River had lower nutrient contents and higher water transparency (especially the Paraná main channel) (Figure 3c). The other connected and disconnected lakes, together with the Baía River (a semi-lotic environment) had intermediate scores (Figure 3c).

The sampling series conducted in February-March 2002 and March 2008 coincided with high waters (levels $>4.5 \mathrm{~m}$ ). These floods clearly increased the similarity among the habitats of the floodplain, as shown by the reduction of the differences among the first PCA scores in these two series (Figure 3d).
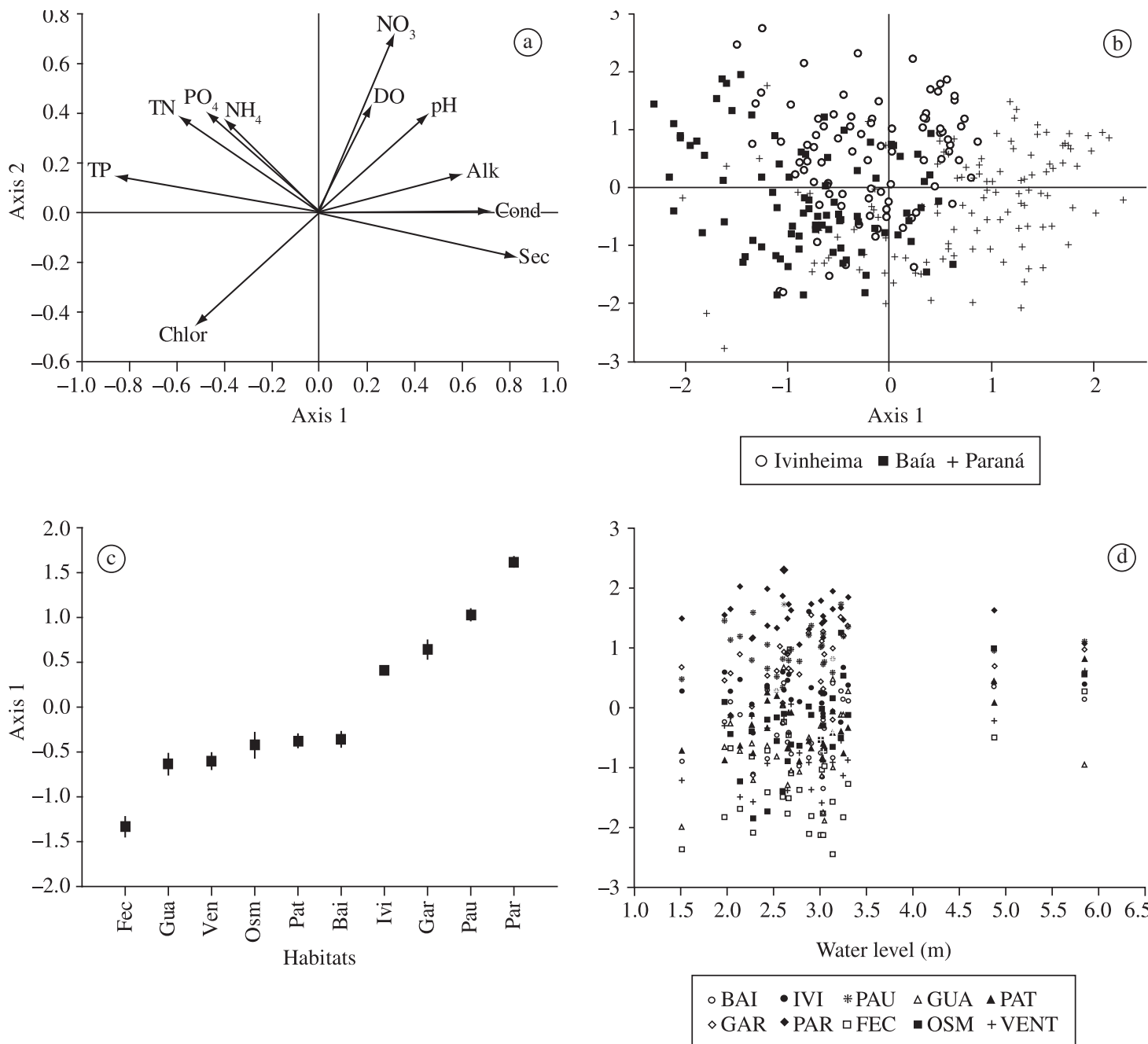

Figure 3. a) Scores of the limnological variables, b) score distributions of habitats along the first two principal-components axes, c) mean ( \pm Standard Error) of the scores of the first principal-components axis, and d) relationship between water level of the Paraná River and the scores of the first principal-components axis. In a): TN $=$ total $-\mathrm{N}$, TP $=$ total $-\mathrm{P}$, Chlor $=$ chlorophyll, $\mathrm{NH}_{4}=\mathrm{N}$-ammonia, $\mathrm{NO}_{3}=\mathrm{N}$-nitrate $\mathrm{PO}_{4}^{3-}=$ P-reactive, $\mathrm{DO}=$ dissolved oxygen, Alk = alkalinity, Cond $=$ conductivity and Sec $=$ Secchi disk. In c) and d): Fec $=$ Fechada Lake, Gua $=$ Guaraná Lake, Vent $=$ Ventura Lake, Osm = Osmar Lake, Pat = Patos Lake, Bai = Baía River, Ivi = Ivinheima River, Gar = Garças Lake, Pau = Pau-véio Lake, and Par $=$ Paraná River. 


\subsection{Long-term trends}

Comparisons with data obtained in the 1980s and 1990s show a clear increase in transparency, as measured by Secchi-disk depth (1.0 $\mathrm{m} \pm 0.5 \mathrm{SD}$ in 1986-1988; $1.4 \mathrm{~m} \pm 0.4 \mathrm{SD}$ in 1992-1994 and $3.0 \mathrm{~m} \pm 1.2 \mathrm{SD}$ in 20002008 ), and a decrease in total phosphorus concentrations $\left(27 \mu \mathrm{g} . \mathrm{L}^{-1} \pm 12 \mathrm{SD}\right.$ in $1987-1988 ; 16 \mu \mathrm{g} . \mathrm{L}^{-1} \pm 9 \mathrm{SD}$ in 1993-1994 and $12 \mu \mathrm{g} . \mathrm{L}^{-1} \pm 8$ SD in 2000-2008) in the Paraná River main channel (Figure 4). Although the trend is less clear, a decrease in phosphorus concentrations was also observed in the waters of the Ivinheima River: from $60 \mu \mathrm{g} . \mathrm{L}^{-1} \pm 23 \mathrm{SD}$ in $1987-1988$, to $44 \mu \mathrm{g} . \mathrm{L}^{-1} \pm 11 \mathrm{SD}$ in 1992-1994 and to $39 \mu \mathrm{g} . \mathrm{L}^{-1} \pm 13 \mathrm{SD}$ in $2001-2008$.

Total phosphorus concentrations in the floodplain lakes usually decreased during floods. This is indicated by negative correlations between the Paraná River water level and total-P in the lakes: $\mathrm{r}=-0.37 ; \mathrm{p}=0.005$; $\mathrm{n}=56$ for the Paraná lakes; $\mathrm{r}=-0.28 ; \mathrm{p}=0.035 ; \mathrm{n}=59$ for the Baía lakes; $\mathrm{r}=-0.30 ; \mathrm{p}=0.022 ; \mathrm{n}=56$ for the Ivinheima lakes (Figure 5). To test the consistency of these correlations, we repeated the analyses after excluding the data from the exceptionally large 2002 and 2007 floods. For the Paraná and Baía lakes, the correlations remained significant $(\mathrm{r}=-0.36 ; \mathrm{p}=0.009 ; \mathrm{n}=52$
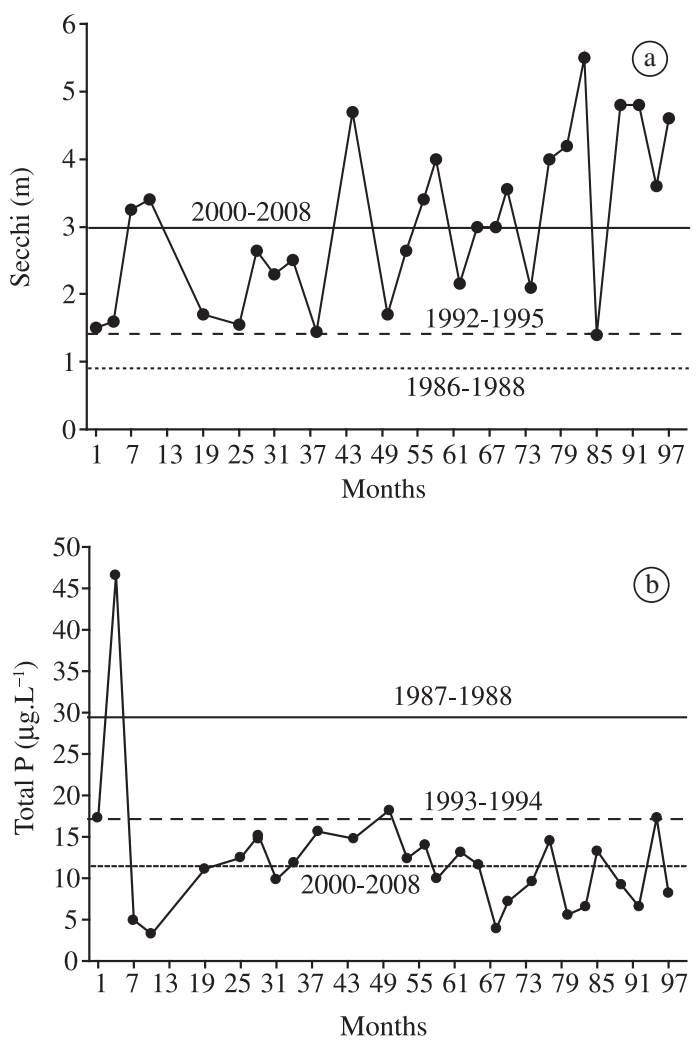

Figure 4. a) Secchi disk values and b) total-P recorded from February 2000 (month 1) to February 2008 (month 97) in the Paraná River main channel. Mean values obtained in 1986-1988 and 1992-1995 (for Secchi disk), and 1987-1988 and 1993-1994 (for total-P) are also shown. and $\mathrm{r}=-0.28 ; \mathrm{p}=0.040 ; \mathrm{n}=55$, respectively), but the correlation was not significant for the Ivinheima lakes $(\mathrm{r}=-0.11 ; \mathrm{p}=0.409 ; \mathrm{n}=53)$.

\section{Discussion}

\subsection{Spatial patterns}

The wide range of several limnological variables (e.g., oxygen: 0.2-10.9 mg.L $\mathrm{L}^{-1}$; alkalinity: 12-515 mEq. $\mathrm{L}^{-1}$; total nitrogen: $89-4473 \mu \mathrm{g} . \mathrm{L}^{-1}$ ) indicates that these floodplain aquatic habitats are highly diverse in their physical and chemical properties. Considering only phosphorus (3-313 $\mu \mathrm{g} . \mathrm{L}^{-1}$ ) and chlorophyll (not detected-89 $\mu \mathrm{g} . \mathrm{L}^{-1}$ ), for example, the habitats can be characterized as oligo- to hypereutrophic (Tundisi, 1990). This wide range of abiotic conditions indicates great habitat diversity, which may partially explain the high biodiversity over large spatial scales in the floodplain (Agostinho et al., 2000). Habitat diversity is important to explain the species richness of several assemblages in wetlands (e.g., Tockner et al., 2000; Guadagnin and Maltchik, 2007; Rolon et al., 2008).

Part of the range obtained in our samples can be attributed to water-level fluctuations, because abiotic features are greatly affected by changes in depth and water velocity. The water levels of the Ivinheima and Baía rivers fluctuate independently of levels in the Paraná (Souza Filho et al., 2005), and this pattern also contributes to increase habitat heterogeneity among different riverine habitats in the floodplain.

In addition, the peculiarities of each river increase this habitat heterogeneity. This was clearly shown by the PCA results, which separated habitats according to their position in the floodplain. For example, the Paraná River main channel and its connected habitats have higher water transparency and lower phosphorus concentrations; the Baía habitats have higher total-N and total-P concentrations; and the Ivinheima River habitats have

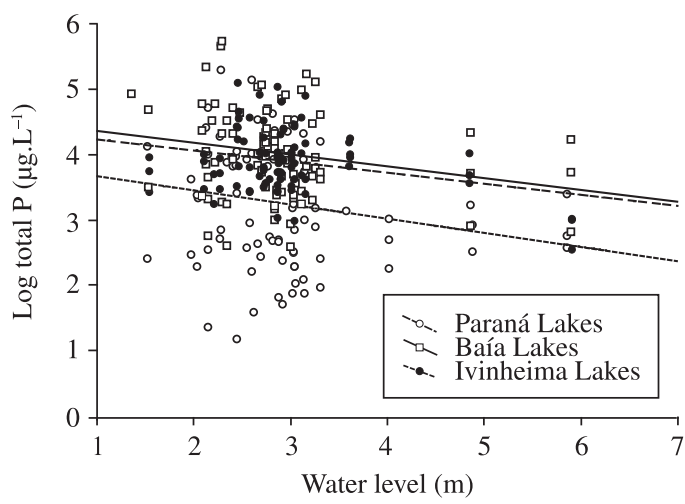

Figure 5. Relationship between water level of the Paraná River and phosphorus concentrations in lakes associated with three different rivers in the Upper Paraná River floodplain. 
slightly higher $\mathrm{N}$-ammonium and reactive-P. These differences may help to explain the distribution of species in the floodplain, and even the success of some species in certain habitats. For example, the increase and dominance of rooted submersed macrophytes (e.g., Egeria najas Planch. and Hydrilla verticillata (L.f.) Royle) are observed mainly in the Paraná main channel and its associated habitats, and are due to the higher water transparency of these habitats (Thomaz et al., 2009). Similarly, the increase of peacock bass (Cichla kelberi Kullander and Ferreira, 2006) in the Paraná River may be explained by higher water transparency in this river, what has been shown for other Neotropical ecosystems (e.g., Fugi et al., 2008).

The highest values of chlorophyll and nutrients (including all forms of nitrogen and phosphorus), together with the lowest Secchi depth values, were obtained in isolated and connected lakes. These habitats are quite shallow (in general, depths $<3.0 \mathrm{~m}$ ), which favors sediment resuspension through wind action and diel mixing, with consequent inputs of seston and nutrients to the water column. This process occurs mainly during low-water periods, and is common in lakes of many river-floodplain systems (Esteves et al., 1994; Carvalho et al., 2001). Fertilization during high-water periods may also occur from river contribution and/or plant biomass decomposition, what also decreases oxygen in water column (Camargo and Esteves, 1995; Pagioro and Thomaz, 1999; Taniguchi et al., 2004; Thomaz et al., 2004; Bianchini Jr. et al., 2008). However, in the Paraná floodplain fertilization from rivers during floods is important only habitats connected to the Baía and Ivinheima rivers, which carry more nutrients than the Paraná River (see "Long-term trends", below)

Our data also suggest that the floodplain aquatic habitats become more dissimilar during low-water periods (see Figure 3d). Similar patterns have been widely described (e.g., Tockner and Ward, 1999; Amoros and Bornette, 2002; Taniguchi et al., 2004; Thomaz et al., 2007; Palijan et al., 2008), and are caused mainly by the influence of local driving forces during low-water periods and by the increased connectivity and exchange of materials and organisms during high-water periods. The consequences for biodiversity maintenance can also be important, as highlighted by Thomaz et al. (2007).

\subsection{Long-term trends}

Two clear changes were observed when comparing the present data set with data obtained in the 1980-1990s: an increase in Secchi depth, and a decrease in phosphorus concentrations in the Paraná River. These modifications coincided with the closing in 1998 of the Porto Primavera Reservoir, located just upstream from the floodplain. Reservoirs trap sediments and phosphorus (Thornton, 1990; Henry and Nogueira, 1999). Although Porto Primavera may have accelerated these changes, they are also caused by the several reservoir cascades in the Upper Paraná basin, which existed be- fore the Porto Primavera construction. High retention of phosphorus together with increase in water transparency has been shown, for example, in the reservoir cascade of the Tietê River, located upstream from the floodplain (Barbosa et al., 1999). In the Paranapanema River, also located upstream from the floodplain, an increase in phosphorus occurs in the middle of the cascade, but the water released by the last reservoir also has low phosphorus concentrations (Nogueira et al., 2006). Thus, it is tempting to conclude that the reservoir construction, in addition to increasing water transparency, has changed the nutrient dynamics in the entire floodplain. As a result, the water from the Paraná River, which carries very low $\mathrm{P}$ concentrations (total-P concentrations usually $<12 \mu \mathrm{g} . \mathrm{L}^{-1}$; see Figure 4 ), is probably diluting the floodplain during floods, which may well have negative consequences for this ecosystem over the long term.

This suggestion was confirmed by the correlations observed between the Paraná River water level and the phosphorus concentrations in the floodplain lakes. During major floods, when the Paraná water covers the entire floodplain (as in February-March 2002, January-February 2005, and January-March 2007), the dilution effect may be very important and may affect the entire floodplain. On the other hand, during normal, smaller floods, dilution probably occurs only in the lakes directly connected to the Paraná River, and to a lesser extent in habitats connected to the Baía River. The Ivinheima habitats are probably not affected by dilution, except during major floods. This scenario was also confirmed by our correlation data, which showed that the relationship between total-P of the Ivinheima lakes and the Paraná water level becomes non-significant if major flood events are removed from the analyses. Thus, in contrast to the Paraná River, the Baía and especially the Ivinheima rivers may make important contributions of nutrients to their associated lakes. In turn, differences in nutrients may explain spatial patterns observed between habitats in the floodplain. Higher periphyton biomasses, for example, are usually measured in the Ivinheima River, which carries more phosphate than the Paraná (Leandrini et al., 2008).

In summary, our results revealed wide variability in the physical and chemical characteristics of habitats in the floodplain, which is caused by the distinct characteristics of the rivers that enter the plain. This high habitat heterogeneity may have an important role in maintaining the biological diversity over large spatial scales in the floodplain. The long-term data indicated a steep increase in water transparency and decrease in phosphorus of the Paraná River water after 2000. These changes, caused by the cascades of reservoirs located upstream from the floodplain, were probably enhanced by the construction of the Porto Primavera Reservoir just upstream from the floodplain. We predict that these alterations i) facilitated the colonization of the floodplain by species (both exotic and native) that depend on underwater radiation (e.g., submersed plants and visual predators, already 
noted in the floodplain waterbodies) and ii) will reduce the productivity of the floodplain over long time scales. These conclusions must considered for the development of management plans to maintain the biodiversity and the ecosystem functions of this important stretch of the Paraná River.

Acknowledgements - We appreciate the assistance of Thomaz A. Pagioro in the field, and Thiago A. M. Lopes, Beatriz S. Toyshima, Michelle Moura, and Priscilla B. Mendes in the laboratory. S. M. Thomaz is especially thankful to the Brazilian Council of Research $(\mathrm{CNPq})$, for continuous funding through a Research Productivity Grant. This research was funded by $\mathrm{CNPq} / \mathrm{MCT}$ through the Long-Term Ecological Research Program, site number 6.

\section{References}

AGOSTINHO, AA., THOMAZ, SM., MINTE-VERA, CV. and WINEMILLER, KO., 2000. Biodiversity in the high Paraná River floodplain. In GOPAL, B., JUNK, WJ. and DAVIS, JA. (Eds.). Biodiversity in Wetlands: assessment, function and conservation. Leiden: Backhuys Publishers. p. 89-118.

AGOSTINHO, AA. and ZALEWSKI, M., 1995. The dependence of fish community structure and dynamics on floodplain riparian ecotone zone in Paraná River, Brazil. Hydrobiologia, vol. 303, no. 1-3, p. 141-148.

AMOROS, C. and BORNETTE, G., 2002. Connectivity and biocomplexity in waterbodies of riverine floodplains. Freshwater Biology, vol. 47, no. 4, p. 761-776.

BARBOSA, FAR., PADISÁK, J., ESPÍNDOLA, ELG., BORICS, G. and ROCHA, O., 1999. The cascading reservoir continuum concept (CRCC) and its application to the River Tietê-basin, São Paulo State, Brazil. In TUNDISI, JG. and STRAŠKRABA, M. (Eds.). Theoretical reservoir ecology and its applications. São Carlos; Rio de Janeiro; Leiden: IIE; BAS; Backhuys Publishers. p. 425-438.

BERGAMIN, H., REIS, BF. and ZAGATTO, EAG., 1978. A new device for improving sensitivity and stabilization in flow injection analysis. Analytica Chimica Acta, vol. 97, p. 427-431.

BIANCHINI Jr., I., CUNHA-SANTINO, MB. and PERET, AM., 2008. Oxygen demand during mineralization of aquatic macrophytes from an oxbow lake. Revista Brasileira de Biologia = Brazilian Journal of Biology, vol. 68, no. 1, p. 61-67.

CAMARGO, AFM. and ESTEVES, FA., 1995. Influence of water-level variation on fertilization of an oxbow lake of Rio Mogi-Guaçu, State of São Paulo, Brazil. Hydrobiologia, vol. 299, no. 3, p. 185-193.

CARMOUZE, JP., 1994. O metabolismo dos ecossistemas aquáticos: fundamentos teóricos, métodos de estudo e análises químicas. São Paulo: Edgard Blücher. p. 253.

CARVALHO, P., BINI, LM., THOMAZ, SM., OLIVEIRA, LG., ROBERTSON, B., TAVECHIO, WLG. and DARWISCH, AJ., 2001. Comparative limnology of South-American lakes and lagoons. Acta Scientiarum, vol. 23, no. 2, p. 265-273.

ESTEVES, FA., THOMAZ, SM. and ROLAND, F., 1994. Comparison of the metabolism of two floodplain lakes of the Trombetas River (Pará, Brazil) based on a study of diel variation. Amazoniana, vol. XIII, no. 1-2, p. 33-46.
Fundação Universidade Estadual de Maringá-FUEM, Programa de Apoio ao Desenvolvimento Científico e Tecnológico - PADCT and Ciências Ambientais - CIAMB, 1995. Estudos ambientais da planície de inundação do rio Paraná no trecho compreendido entre a foz do rio Paranapanema e o reservatório de Itaipu. Maringá: FUEM; PADCT; CIAMB. Report- support, PADCT/ CIAMB.

FUGI, R., LUZ-AGOSTINHO, KDG. and AGOSTINHO, AA., 2008. Trophic interaction between an introduced (peacock bass) and a native (dogfish) piscivorous fish in a Neotropical impounded river. Hydrobiologia, vol. 607, no. 1, p. 143-150.

GINÉ, MF., BERGAMIN, FH., ZAGATTO, EAG. and REIS, BF., 1980. Simultaneous determination of nitrate and nitrite by flow injection analysis. Analytica Chimica Acta, vol. 114, p. $191-197$

GOLTERMAN, HL., CLYMO, RS. and OHMSTAD, MAM., 1978. Methods for physical and chemical analysis of fresh water. Oxford: Blackwell Scientific. 214p.

GUADAGNIN, DL. and MALTCHIK, L., 2007. Habitat and landscape factors associated with neotropical waterbird occurrence and richness in wetland fragments. Biodiversity and Conservation, vol. 16, no. 4, p. 1231-1244.

HENRY, R. and NOGUEIRA, MG., 1999. A represa de Jurumirim: primeira síntese sobre o conhecimento limnológico e uma proposta preliminar de manejo ambiental. In HENRY, R. (Ed.). Ecologia de reservatórios: ecologia, funções e aspectos sociais. Botucatu: FAPESP; FUNDIBIO. p. 653-685.

HOEINGHAUS, DJ., WINEMILLER, KO. and AGOSTINHO, AA., 2008. Hydrogeomorphology and river impoundment affect food-chain length of diverse Neotropical food webs. Oikos, vol. 117 , no. 7, p. 984-995.

JUNK, WJ., BAYLEY, PB. and SPARKS, RE., 1989. The flood pulse concept in river-floodplain systems. Canadian Special Publication of Fisheries and Aquatic Sciences, vol. 106, p. 110-127.

LEANDRINI, JA., FONSECA, IA. and RODRIGUES, L., 2008. Characterization of habitats base don algal periphyton biomass in the upper Paraná River floodplain, Brazil. Revista Brasileira de Biologia = Brazilian Journal of Biology, vol. 68, no. 3, p. 503-509.

LEIRA, M. and CANTONATI, M., 2008. Effects of water-level fluctuations on lakes: an annotated bibliography. Hydrobiologia, vol. 613, no. 1, p. 171-184.

MacKERETH, FYH., HERON, J. and TALLING, JJ., 1978. Water analysis: some revised methods for Limnologists. Freshwater Biological Association, vol. 36, p. 1-120.

MARCHESE, MR., WANTZEN, KM. and De DRAGO, IE., 2005. Benthic invertebrate assemblages and species diversity patterns of the Upper Paraguay River. River Research and Applications, vol. 21, no. 5, p. 485-499.

NEIFF, JJ., 1990. Ideas para la interpretacion ecológica del Parana. Interciencia, vol. 5, no. 6, p. 424-441.

2001. Diversity in some tropical wetlands systems of South America. In GOPAL, B., JUNK, WJ. and DAVIS, JA. (Eds.). Biodiversity in Wetlands: assessment, function and conservation. Leiden: Backhuys. p. 157-186

NOGUEIRA, MG., JORCIN, A., VIANNA, NC. and De BRITTO, YCT., 2006. Reservatórios em cascata e os efeitos 
na limnologia e organização das comunidades bióticas (fitoplâncton, zooplâncton e zoobentos): um estudo de caso no rio Paranapanema. In NOGUEIRA, MG., HENRY, R. and JORCIN, A. (Eds.). Ecologia de reservatórios: impactos potenciais, ações de manejo e sistemas em cascata. São Carlos: RiMa. p. 83-125.

PAGIORO, TA. and THOMAZ, SM., 1999. Decomposition of Eichhornia azurea from limnologically different environments of the Upper Paraná River floodplain. Hydrobiologia, vol. 411, p. $45-51$.

PALIJAN, G., BOGUT, I. and VIDAKOVIĆ, J., 2008. The impact of inundation-isolation cycles on the culturable bacterioplankton in the Danube River floodplain. Polish Journal of Ecology, vol. 56, no. 3, p. 391-403.

ROLON, AS., LACERDA, T., MALTCHIK, L. and GUADAGNIN, DL., 2008. Influence of area, habitat and water chemistry on richness and composition of macrophyte assemblages in southern Brazilian wetlands. Journal of Vegetation Science, vol. 19, no. 2, p. 221-228.

SOUZA FILHO, EL., COMUNELlO, E. and ROCHA, PC., 2005. Flood extension in the Baía-Curutuba-Ivinheima complex of the Paraná River floodplain. In AGOSTINHO, AA., RODRIGUES, L., GOMES, LC., THOMAZ, SM. and MIRANDA, SL. (Eds.). Structure and functioning of the upper Paraná River and its floodplain. Maringá: EDUEM. p. 19-24.

TANIGUCHI, GM., BICUDO, DC. and SENNA, PA., 2004. Abiotic variables in littoral-limnetic gradient of an oxbow lake of Mogi-Guaçu River floodplain, Southeastern Brazil. Brazilian Archives of Biology and Technology, vol. 47, no. 6, p. 961-971.

THOMAZ, SM., 1991. Influência d regime hidrológico (pulsos) sobre algumas variáveis limnológicas de diferentes ambientes aquáticos da planície de inundação do alto rio Paraná, MS,
Brasil. São Carlos: Universidade Federal de São Carlos. 294p. Dissertação de Mestrado.

THOMAZ, SM., PAGIORO, TA., BINI, LM., ROBERTO, MC. and ROCHA, RRA., 2004. Limnological characterization of the aquatic environments and the influence of hydrometric levels. In THOMAZ, SM., AGOSTINHO, AA. and HAHN, NS. (Eds.). The Upper Paraná River and its floodplain: physical aspects, ecology and conservation. Leiden: Backhuys Publishers. p. 75-102.

THOMAZ, SM., BINI, LM. and BOZELLI, RL., 2007. Floods increase similarity among aquatic habitats in river-floodplain systems. Hydrobiologia, vol. 579, no. 1, p. 1-13.

THOMAZ, SM., CARVALHO, P., PADIAL, AA. and KOBAYASHI, JT., 2009. Temporal and spatial patterns of aquatic macrophytes diversity in the Upper Paraná River floodplain. Revista Brasileira de Biologia = Brazilian Journal of Biology, vol. 69 no. (2 suppl.), p. 617-625.

THORNTON, KW., 1990. Sedimentary processes. In KIMMEL, BL. and PAYNE, FE. (Eds.). Reservoir limnology: ecological perspectives. New York: John Wiley and Sons. p. 43-69.

TOCKNER, K., MALARD, F. and WARD, JV., 2000. An extension of the flood pulse concept. Hydrological Processes, vol. 14, no. 16-17, p. 2861-2883.

TOCKNER, K. and WARD, JV., 1999. Biodiversity along riparian corridors. Large Rivers, vol. 11, no. 3, p. 293-310.

TUNDISI, JG., 1990. Key factors of reservoir functioning and geographical aspects of reservoir limnology chairman's overview. Archiv für Hydrobiologie, vol. 33, no. 3, p. 645-646.

TUNDISI, JG. and MATSUMURA-TUNDISI, T., 2008. Limnologia. São Paulo: Oficina de Textos. 631p. 